\title{
Soluble neprilysin and long-term clinical outcomes in patients with coronary artery disease undergoing percutaneous coronary intervention: a retrospective cohort study
}

Ik Jun Choi ${ }^{1}$, Sungmin Lim² ${ }^{2 *}$, Youngdeok Hwang ${ }^{3}$, Dongjae Lee ${ }^{1}$, Won Jik Lee ${ }^{1}$, Kwan Yong Lee ${ }^{1}$ Mi-Jeong $\mathrm{Kim}^{1}$ and Doo Soo Jeon ${ }^{1}$

\begin{abstract}
Background: Neprilysin has an essential role in regulating fluid balance and vascular resistance, and neprilysin inhibitors have shown beneficial effects in patients with heart failure. However, the potential predictive value of neprilysin levels as a biomarker for cardiovascular risk remains unclear. The aim of this study was to assess the prognostic value of soluble neprilysin (sNEP) levels in patients with ischemic heart disease.
\end{abstract}

Methods: Neprilysin levels were measured in 694 consecutive patients with coronary artery disease (CAD) undergoing percutaneous coronary intervention ( $\mathrm{PCl}$ ). These patients were classified into two groups according to their serum levels of neprilysin and categorized into the lower neprilysin group $(n=348)$ and the higher neprilysin group $(n=346)$. The primary clinical endpoint was all-cause mortality, and the secondary endpoint was a composite of major adverse cardiac events (MACE).

Results: The median sNEP level was $76.0 \mathrm{pg} / \mathrm{ml}$. The median sNEP levels were higher in patients with left ventricular ejection fraction (LVEF) $\geq 40 \%(77.6 \mathrm{pg} / \mathrm{ml}$, interquartile range 46.6-141.3) than in those with LVEF $<40 \%$ (70.0 pg/ml, interquartile range 47.1-100.6; $P=0.032$ ). Among all patients, each clinical outcome and MACE did not differ significantly according to the groups divided into median, tertile, or quartile of sNEP levels during a median follow-up of 28.4 months. We did not find a significant relationship between sNEP levels and clinical outcomes in multivariate Cox regression analysis. Among patients with LVEF $<40 \%$, an increased sNEP level was associated with a higher rate of all-cause death (adjusted hazard ratio 2.630, 95\% confidence interval 1.049-6.595, $P=0.039$ ).

Conclusion: Serum sNEP levels are not associated with long-term mortality or cardiovascular outcomes after $\mathrm{PCl}$ in patients with CAD. In the LVEF < 40\% group, increased sNEP levels may be associated with a higher risk of all-cause death.

Keywords: Neprilysin, Coronary artery disease, Percutaneous coronary intervention, Prognosis, Left ventricular ejection fraction

\footnotetext{
* Correspondence: mdsungminlim@gmail.com

${ }^{2}$ Division of Cardiology, Department of Internal Medicine, Uijeongbu St.

Mary's Hospital, College of Medicine, The Catholic University of Korea, 271,

Cheonbo-ro, Uijeongbu-si, Gyeonggi-do, 11765 Seoul, Republic of Korea

Full list of author information is available at the end of the article
}

(C) The Author(s). 2020 Open Access This article is licensed under a Creative Commons Attribution 4.0 International License, which permits use, sharing, adaptation, distribution and reproduction in any medium or format, as long as you give appropriate credit to the original author(s) and the source, provide a link to the Creative Commons licence, and indicate if changes were made. The images or other third party material in this article are included in the article's Creative Commons. licence, unless indicated otherwise in a credit line to the material. If material is not included in the article's Creative Commons licence and your intended use is not permitted by statutory regulation or exceeds the permitted use, you will need to obtain permission directly from the copyright holder. To view a copy of this licence, visit http://creativecommons.org/licenses/by/4.0/. The Creative Commons Public Domain Dedication waiver (http://creativecommons.org/publicdomain/zero/1.0/) applies to the data made available in this article, unless otherwise stated in a credit line to the data. 


\section{Background}

Neprilysin (NEP) is a zinc-dependent type II integral membrane peptidase that degrades a variety of vasoactive peptides such as atrial natriuretic peptide, brain or B-type natriuretic peptide, bradykinin, adrenomedullin, and endothelin-1 [1-3]. These vasoactive peptides play essential roles in fluid balance and vascular resistance [4-6]. Therefore, efforts have been made to inhibit neprilysin as a treatment target for heart failure (HF), and recent clinical trials have obtained remarkable results. Combined inhibition of NEP and angiotensin have been established the effective therapeutic value in patients with HF and reduced ejection fraction (HFrEF) or acute HF [7-9].

Circulating NEP levels were significantly associated with cardiovascular death or HF hospitalization in patients with HFrEF [10]. In addition, previous studies identified a positive association in acute $\operatorname{HF}[11,12]$, whereas other studies did not confirm an association of soluble NEP (sNEP) and cardiovascular mortality and morbidity in patients with HF and preserved ejection fraction (HFpEF) and ST-segment elevation myocardial infarction $[13,14]$. The impact of sNEP levels on clinical outcomes in patients with ischemic heart disease has not been well established. Therefore, the present study aimed to demonstrate the association between serum sNEP levels and mortality and cardiovascular events in patients with coronary artery disease (CAD) undergoing percutaneous coronary intervention (PCI).

\section{Methods}

\section{Study population}

Between September 2015 and Novermber 2017, 796 patients with CAD scheduled for PCI and older than 20 years were screened. Exclusion criteria were as follows: patients with cardiogenic shock, patients with end-stage renal disease and on dialysis, patients who managed conservative care without coronary intervention, and patients without sufficient blood samples. Of the 796 eligible patients, 694 had samples available for measurement of serum levels of neprilysin. All participants provided written informed consent to participate before PCI and blood sampling. The study protocol was reviewed and approved by the appropriate institutional review board.

PCI was performed according to standard techniques and left to the operators' discretion. After the procedure, all patients were recommended to receive optimal pharmacological therapy, including dual-antiplatelets, statins, beta-blockers, or renin-angiotensin blockade, if indicated, following standard European and American guidelines [15-18]. Clinical follow-up was performed every 3 months after the index procedure.

\section{Laboratory measurement}

Blood was drawn upon arrival at the catheterization laboratory and was collected immediately after sheath insertion and before the PCI. After the blood was centrifuged, plasma was subsequently stored at $-80^{\circ} \mathrm{C}$. Serum sNEP levels were measured by an optimized enzyme-linked immunosorbent assay (ELISA) using a High-Sensitivity Soluble Neprilysin (Human) ELISA Kit (Aviscera Bioscience, INC., Santa Clara, CA, USA). The measurement of neprilysin levels was performed in the Clinical Research Laboratory, Incheon St. Mary's Hospital, The Catholic University of Korea.

\section{Study endpoints and definitions}

The primary endpoint was all-cause death. The secondary endpoint was major adverse cardiovascular events (MACE), including cardiovascular death, nonfatal myocardial infarction, nonfatal stroke, any revascularization, and hospitalization for HF. Patient follow-up data, including censored survival data, were collected through March 31, 2019, via hospital chart review, telephone interviews with patients by trained reviewers who were blinded to the study results, and reviews of the database of the National Health Insurance Corporation, Korea, using a unique personal identification number.

Myocardial infarction was defined as an elevation of a cardiac enzyme level, especially high-sensitivity troponin $\mathrm{T}$, above the upper limit with ischemic symptoms or electrocardiographic findings indicative of ischemia that was not related to the PCI. Stroke was defined as any nonconvulsive focal or global neurological deficit of abrupt onset lasting more than $24 \mathrm{~h}$ caused by ischemia or hemorrhage within the brain. Revascularization was defined as any repeat PCI which was unexpected and clinically indicated revascularization. Planed and staged interventions were not considered as repeat revascularization. All events were adjudicated by two interventional cardiologists.

\section{Statistical analysis}

Continuous variables are expressed as the mean \pm standard deviation or median (interquartile range (IQR)) and were analyzed by independent sample $t$-test or the Mann-Whitney $U$-test according to the distribution. Categorical variables are presented as percentages or rates and were analyzed by the chi-square test or Fisher's exact test. A comparison of clinical outcomes between groups was performed with the long-rank test. Receiver operating characteristic (ROC) curve analyses were performed to identify the optimal cutoff value of neprilysin associated with clinical outcomes. Kaplan-Meier curves were used to analyze the overall survival rate and adverse events of patients. Cox proportional hazard models were applied to analyze the hazard ratio (HR) and 95\% 
confidence interval (CI) for clinical outcomes. We examined the association between sNEP levels on a continuous scale and all-cause mortality or adverse cardiovascular events during the follow-up period using the Cox proportional hazard model. All analyses were 2tailed, and $P<0.05$ was considered statistically significant. All statistical analyses were performed using SPSS 20.0 statistical software (SPSS Inc., Chicago, IL, USA) and $\mathrm{R}$ version 3.6.1 (R Foundation for Statistical Computing, Vienna, Austria).

\section{Results}

\section{Study population and characteristics}

The mean age of all available 694 patients was $65.9 \pm$ 11.9 years old, and $67.0 \%$ of the patients were men. Among them, $48.0 \%$ were diagnosed with myocardial infarction. The mean left ventricular ejection fraction (LVEF) was $55.0 \pm 11.7 \%$, and LVEF $<40 \%$ was observed in $86(12.4 \%)$ patients. The median serum neprilysin level was $76.0 \mathrm{pg} / \mathrm{ml}$ (IQR 46.8 to 133.9). Table 1 presents the baseline characteristics according to the groups divided by the median neprilysin level. The age of the neprilysin $\leq 76.0 \mathrm{pg} / \mathrm{ml}$ group was significantly younger than that of the neprilysin $>76.0 \mathrm{pg} / \mathrm{ml}$ group. The prevalence of a family history of CAD was higher in the high neprilysin level group. LVEF was not different between groups. Laboratory and procedural data were also similar between the two groups.

The median sNEP levels were higher in patients with LVEF $\geq 40 \%(77.6 \mathrm{pg} / \mathrm{ml}$, IQR 46.6 to 141.3$)$ than in those with LVEF $<40 \%(70.0 \mathrm{pg} / \mathrm{ml}$, IQR 47.1 to 100.6 ; $p=0.032$ ), whereas the median sNEP levels did not differ according to current smoking status, all-cause mortality, or MACE (Fig. 1).

\section{Clinical outcomes}

The median follow-up duration was 28.4 months (IQR 23.4 to 36.2). During the overall follow-up, the incidences of all-cause death and MACE were 6.9 and $6.2 \%$, respectively. The clinical outcomes are presented in Table 2. Among all patients, each clinical outcome and MACE did not differ significantly between the two groups. ROC curve analysis showed that the area under the curve for all-cause death and MACE were 0.547 (95\% CI 0.509-0.584, $P=0.289$ ) and 0.542 (95\% CI $0.504-0.579, P=0.368$ ), respectively (Fig. 2). Figure 3 shows the Kaplan-Meier curves for all-cause death and MACE up to 28.4 months in all patients. When neprilysin was divided into tertiles and quartiles, there were no significant differences in all-cause death or MACE between groups (Table 3). Multivariate Cox regression analysis using various models demonstrated that the higher neprilysin group was not consistently associated with all-cause death or MACE (Table 4). Univariate and multivariate analyses showed that the neprilysin $>76.0$ $\mathrm{pg} / \mathrm{ml}$ group was not a predictor of all-cause death (HR $1.558,95 \%$ CI $0.848-2.863, P=0.153$ ) (Table 5) or MACE (HR 1.450, 95\% CI 0.785-2.679, $P=0.235$ ).

\section{Subgroup analysis}

We stratified the overall patients by age, sex, and important comorbidities. This subgroup analysis revealed consistent trends irrespective of each subgroup except the LVEF $<40 \%$ group (Fig. 4). The LVEF $<40 \%$ group had a trend of a higher rate of all-cause death in the neprilysin $>76.0 \mathrm{pg} / \mathrm{ml}$ group without a statistically significant interaction (HR 2.630, 95\% CI 1.049-6.595, $P$ for interaction $=0.150$ ) and a marginal trend of a higher rate of MACE (HR 3.213, 95\% CI 0.989-10.441, $P$ for interaction $=0.083$ ). In the analysis for an association between SNEP levels in continuous scales and relative hazard for outcomes, the Cox proportional hazard model results suggest that SNEP level is not a significant factor by itself when considered without its interaction with LVEF $(P=0.094)$. However, the detailed analysis indicates that increased sNEP levels are associated with a higher risk of all-cause death and cardiovascular adverse events for patients with decreased LVEF but not for those with preserved LVEF ( $P$ for interaction $=0.003$ for all-cause mortality, $P$ for interaction $=0.004$ for MACE) (Fig. 5).

\section{Discussion}

The current study found that serum sNEP levels are not associated with mortality or cardiovascular outcomes during follow-up. However, increased sNEP levels tend to be associated with a higher risk of all-cause mortality or cardiovascular events in patients with reduced LVEF but not in patients with preserved LVEF.

There are 3 types of natriuretic peptides, atrial, brain or B-type, and C-type [19-22]. Natriuretic peptides have potent effects on sodium and fluid balance, and they have a very important role in various heart diseases $[1$, 23, 24]. Circulating natriuretic peptides are cleared through 2 essential mechanisms: one is natriuretic peptide receptor-mediated clearance, and the other is degradation by enzymes. NEP is one of the most important proteases that cleaves human natriuretic peptides, and the cleavage sites on natriuretic peptides have been well established [1,25]. NEP was isolated for the first time in the 1970s as an endopeptidase in renal proximal tubule cells of rabbits [26, 27]. Since then, several brilliant studies have established the function of NEP. NEP is not only a potent hydrolyzer of natriuretic peptides but also a membrane-bound enzyme that degrades a large number of vasodilator peptides, including adrenomedullin, bradykinin, angiotensin, substance $P$, endothelin-1, and amyloid-beta protein [1, 28-31]. Although NEP is a 
Table 1 Baseline clinical and angiographic characteristics

\begin{tabular}{|c|c|c|c|}
\hline Variables & $\begin{array}{l}\text { Neprilysin } \\
\leq 76.0 \mathrm{pg} / \mathrm{ml} \\
(n=348)\end{array}$ & $\begin{array}{l}\text { Neprilysin } \\
>76.0 \mathrm{pg} / \mathrm{ml} \\
(n=346)\end{array}$ & $P$ value \\
\hline Age (years) & $66.8 \pm 11.2$ & $64.9 \pm 12.4$ & 0.027 \\
\hline Male & $231(66.4 \%)$ & $234(67.6 \%)$ & 0.394 \\
\hline Body mass index $\left(\mathrm{Kg} / \mathrm{m}^{2}\right)$ & $24.5 \pm 4.1$ & $24.5 \pm 4.1$ & 0.983 \\
\hline Hypertension & $238(68.4 \%)$ & $249(72.0 \%)$ & 0.172 \\
\hline Diabetes mellitus & $138(39.7 \%)$ & $124(35.8 \%)$ & 0.169 \\
\hline Dyslipidemia & $123(35.9 \%)$ & $120(35.4 \%)$ & 0.482 \\
\hline Smoking & $90(25.9 \%)$ & $110(31.8 \%)$ & 0.050 \\
\hline Family history of coronary artery disease & $20(5.7 \%)$ & $33(9.5 \%)$ & 0.041 \\
\hline Chronic kidney disease & $16(4.6 \%)$ & $17(4.9 \%)$ & 0.493 \\
\hline Prior stroke & $37(10.6 \%)$ & $37(10.7 \%)$ & 0.538 \\
\hline Prior myocardial infarction & $32(9.2 \%)$ & $23(6.6 \%)$ & 0.135 \\
\hline Prior percutaneous coronary intervention & $46(13.2 \%)$ & $43(12.4 \%)$ & 0.422 \\
\hline Clinical presentation & & & 0.982 \\
\hline Stable angina & $19(5.5 \%)$ & $22(6.4 \%)$ & \\
\hline Unstable angina & $153(44.0 \%)$ & $155(44.8 \%)$ & \\
\hline NSTEMI & $110(31.6 \%)$ & 107 (30.9\%) & \\
\hline STEMI & $60(17.2 \%)$ & $56(16.2 \%)$ & \\
\hline Silent myocardial ischemia & $6(1.7 \%)$ & $6(1.7 \%)$ & \\
\hline Left ventricular ejection fraction (\%) & $54.5 \pm 12.1$ & $55.6 \pm 11.3$ & 0.222 \\
\hline Total cholesterol (mg/dl) & $165.6 \pm 46.3$ & $164.2 \pm 43.2$ & 0.676 \\
\hline Triglyceride (mg/dl) & $141.0 \pm 86.0$ & $154.1 \pm 133.4$ & 0.137 \\
\hline HDL cholesterol (mg/dl) & $41.6 \pm 10.5$ & $41.3 \pm 9.9$ & 0.682 \\
\hline LDL cholesterol (mg/dl) & $101.0 \pm 34.1$ & $99.0 \pm 31.8$ & 0.415 \\
\hline High-sensitivity C-reactive protein (mg/l) & $8.4 \pm 23.9$ & $10.0 \pm 28.0$ & 0.406 \\
\hline eGFR $\left(\mathrm{ml} / \mathrm{min} / 1.73 \mathrm{~m}^{2}\right)$ & $69.6 \pm 26.4$ & $73.8 \pm 30.8$ & 0.056 \\
\hline NT-proBNP (pg/ml) & $1384.0 \pm 4585.9$ & $1919.1 \pm 6243.0$ & 0.199 \\
\hline Culprit lesion & & & 0.628 \\
\hline Left anterior descending & $171(51.5 \%)$ & $165(49.8 \%)$ & \\
\hline Left circumflex & $62(18.7 \%)$ & $54(16.3 \%)$ & \\
\hline Right coronary artery & $83(25.0 \%)$ & $95(28.7 \%)$ & \\
\hline Left main & $15(4.5 \%)$ & $17(5.1 \%)$ & \\
\hline Extent of coronary artery disease & & & 0.256 \\
\hline 1-vessel disease & $164(49.4 \%)$ & $146(44.1 \%)$ & \\
\hline 2-vessel disease & $100(30.1 \%)$ & $119(36.0 \%)$ & \\
\hline 3-vessel disease & $68(20.5 \%)$ & $66(19.9 \%)$ & \\
\hline Multivessel disease & $103(29.6 \%)$ & $112(32.4 \%)$ & 0.240 \\
\hline Number of total stents & $1.6 \pm 1.0$ & $1.7 \pm 1.2$ & 0.139 \\
\hline Mean diameter of stents & $3.10 \pm 0.43$ & $3.11 \pm 0.41$ & 0.677 \\
\hline Total length of stents & $42.2 \pm 28.8$ & $46.8 \pm 35.4$ & 0.065 \\
\hline
\end{tabular}



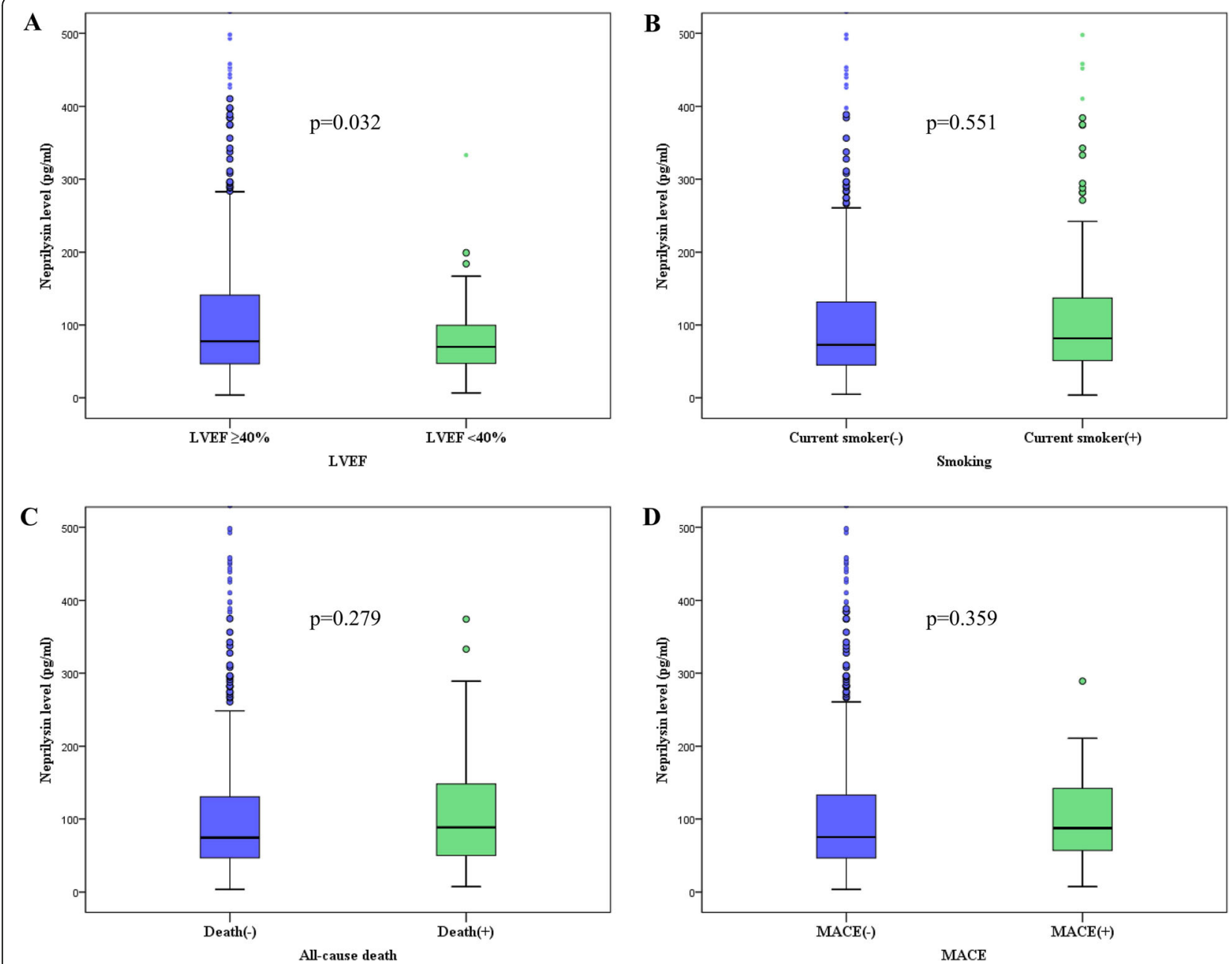

Fig. 1 Comparison of soluble neprilysin levels. a Left ventricular ejection fraction (b) smoking (c) all-cause death (d) major adverse cardiovascular events

Table 2 Clinical outcomes according to the soluble neprilysin level

\begin{tabular}{|c|c|c|c|}
\hline \multirow[t]{2}{*}{ Outcome } & \multicolumn{2}{|l|}{ Neprilysin } & \multirow{2}{*}{$\begin{array}{l}\text { Log } \\
\text { rank, } \\
P \\
\text { value }\end{array}$} \\
\hline & $\begin{array}{l}\leq 76.0 \mathrm{pg} / \mathrm{ml} \\
(n=348)\end{array}$ & $\begin{array}{l}>76.0 \mathrm{pg} / \mathrm{ml} \\
(n=346)\end{array}$ & \\
\hline All-cause death & $20(5.7 \%)$ & $28(8.1 \%)$ & 0.213 \\
\hline Cardiovascular death & $10(2.9 \%)$ & $15(4.3 \%)$ & 0.292 \\
\hline Nonfatal myocardial infarction & $0(0 \%)$ & $1(0.3 \%)$ & 0.316 \\
\hline Nonfatal stroke & $2(0.6 \%)$ & $4(1.2 \%)$ & 0.408 \\
\hline Revascularization & $5(1.4 \%)$ & $5(1.4 \%)$ & 0.968 \\
\hline Hospitalization for heart failure & $3(0.9 \%)$ & $2(0.6 \%)$ & 0.664 \\
\hline Major adverse cardiovascular events & $19(5.5 \%)$ & 24 (6.9\%) & 0.382 \\
\hline
\end{tabular}

membrane-bound metalloprotease, it can be released from the cell membrane. The production of sNEP is known to occur as a consequence of proteolytic cleavage of the extracellular domain or exosomal release dependent on A Disintegrin And Metalloprotease-17 (ADAM-17) [1, 10, 32]. In addition, NEP may exist as either a transmembrane or soluble form, and sNEP retains its catalytic activity $[1,10,33]$.

Circulating sNEP has been reported as a biomarker surrogate in patients with HF. In chronic ambulatory HF patients with at least 1 hospitalization for HF or reduced LVEF, sNEP was positively associated with cardiovascular mortality and morbidity [10]. In comprehensive multivariable analyses, sNEP remained to be significantly associated with both composite endpoint and cardiovascular mortality independent of conventional clinical risk factors and NT-proBNP. Elevated sNEP levels predicted an increased risk of recurrent admission for HF in the same study population with chronic HF [34]. In addition, the 

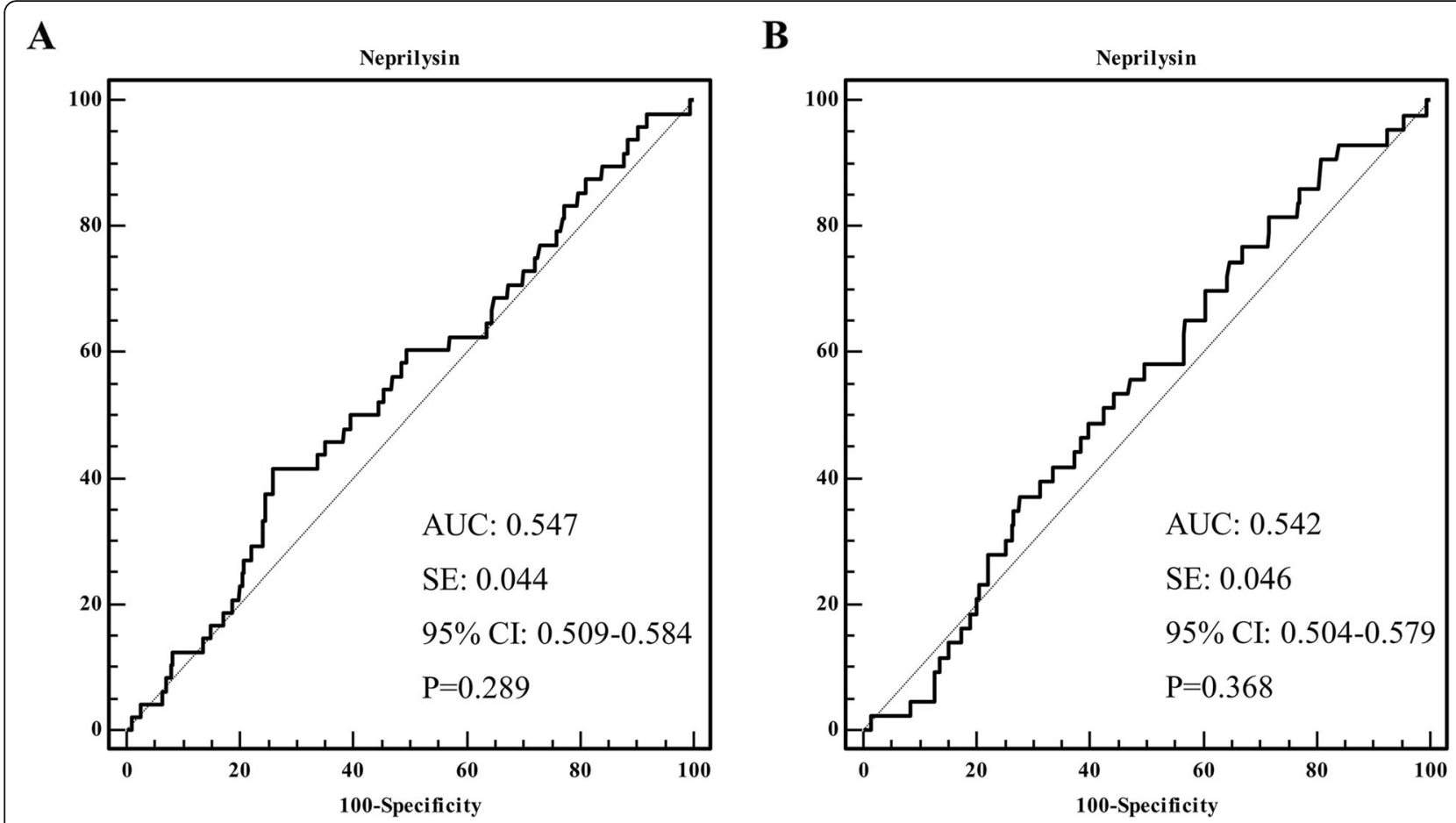

Fig. 2 Receiver operating characteristic curve according to the neprilysin level. a All-cause death and (b) the major cardiovascular events

prognostic value of sNEP has been evaluated in acute decompensated HF [11]. Admission sNEP concentration was associated with short- and long-term outcomes in acute HF. On the other hand, another study could not confirm an association between sNEP levels and cardiovascular mortality or hospitalization for HF in patients with HFpEF [14]. In addition, sNEP levels showed no significant relationship with myocardial infarct size and 1-year adverse outcomes in patients with ST-elevation myocardial infarction [13]. More recently, in a large community-based cohort, the investigators reported that sNEP did not correlate with natriuretic peptide levels and was not independently associated with adverse outcomes [35].

The present study aimed to demonstrate the prognostic value of sNEP levels in patients with CAD undergoing PCI. To the best of our knowledge, this study is the first analysis of SNEP as a prognostic biomarker in allcomer PCI patients. In particular, most of the patients were relatively high-risk patients with acute coronary syndrome. Consequently, the results of this study showed no association between sNEP levels and longterm mortality or major cardiovascular events. However,
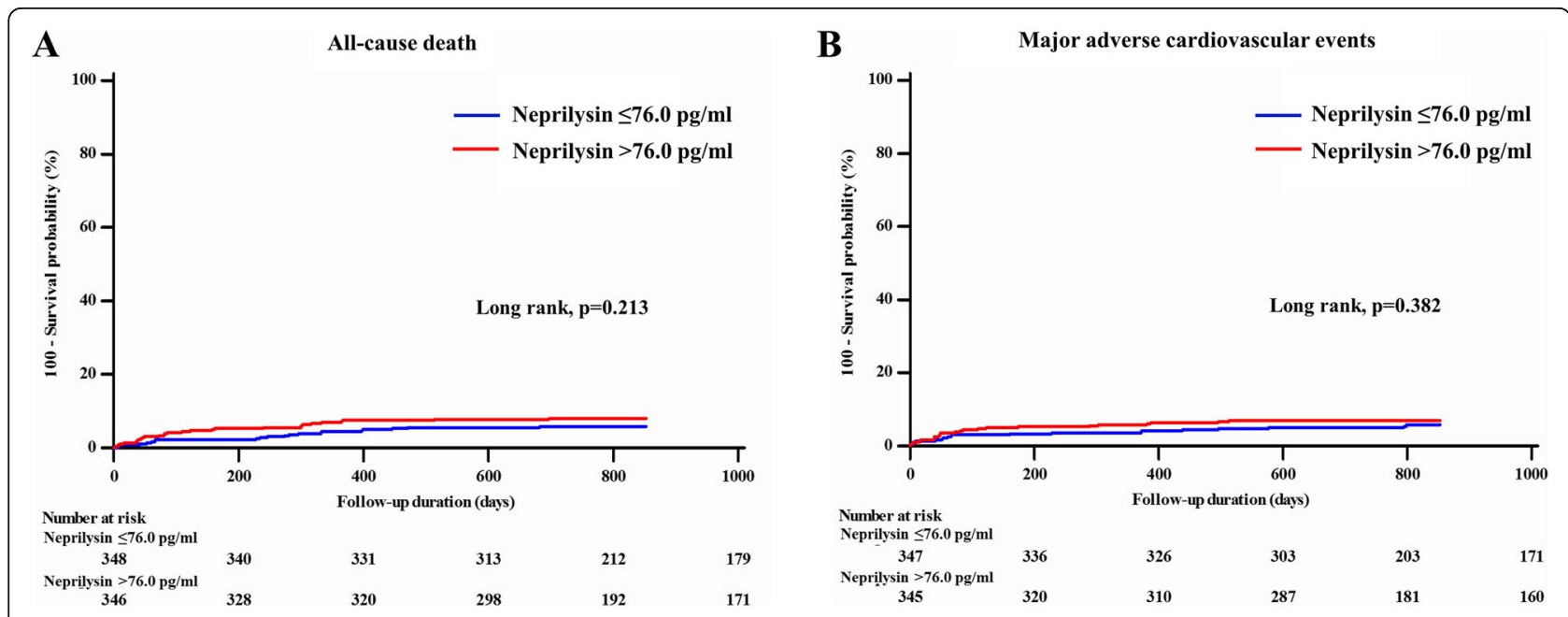

Fig. 3 Cumulative incidence rates according to soluble neprilysin level. a All-cause death and (b) the major cardiovascular events 
Table 3 Clinical outcomes according to the tertile and quartile of the soluble neprilysin level

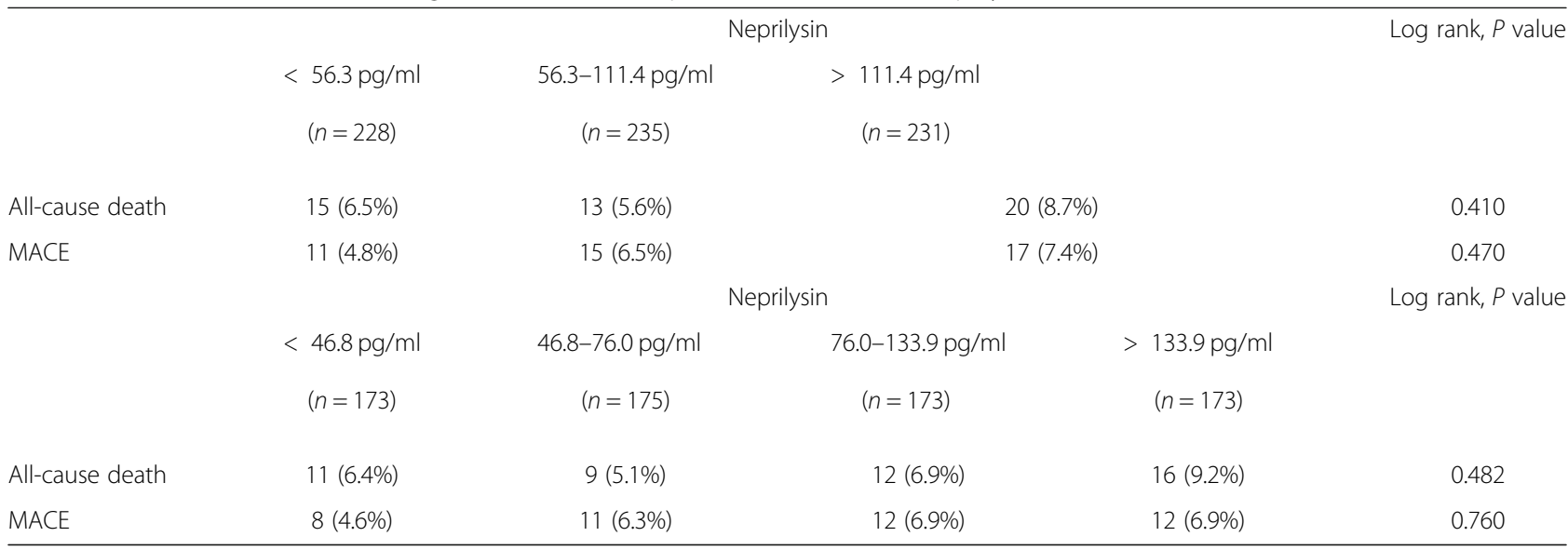

MACE indicates major adverse cardiovascular events

in the subgroup analysis, CAD patients with reduced LVEF seemed to show a positive association between circulating SNEP levels and mortality and MACE, while there was no association between circulating sNEP levels and preserved LVEF. These findings are consistent with the results of previous studies regarding SNEP as a biomarker for long-term clinical outcomes in patients with HFrEF and HFpEF. However, this finding may not be conclusive because only $12.4 \%$ of patients who were included in our study presented with LVEF less than $40 \%$, and the subgroup analysis did not have strong statistical power.

Table 4 Association between the neprilysin level with all-cause death and major adverse cardiovascular events

\begin{tabular}{lll}
\hline Model & HR $(95 \%$ Cl$)$ & $P$ value \\
\hline All-cause death & & \\
Model 1 (univariate) & $1.437(0.810-2.552)$ & 0.215 \\
Model 2 (age, sex) & $1.567(0.882-2.783)$ & 0.125 \\
Model 3 (age, sex, smoking) & $1.575(0.887-2.798)$ & 0.121 \\
Model 4 (age, sex, LVEF) & $1.598(0.898-2.842)$ & 0.111 \\
Model 5 (age, sex. NT-proBNP) & $1.414(0.789-2.534)$ & 0.244 \\
Model 6 & $1.701(0.892-3.247)$ & 0.107 \\
Major adverse cardiovascular events. & & \\
Model 1 (univariate) & $1.307(0.716-2.386)$ & 0.384 \\
Model 2 (age, sex) & $1.431(0.783-2.614)$ & 0.244 \\
Model 3 (age, sex, smoking) & $1.431(0.784-2.613)$ & 0.244 \\
Model 4 (age, sex, LVEF) & $1.528(0.834-2.798)$ & 0.170 \\
Model 5 (age, sex. NT-proBNP) & $1.309(0.705-2.430)$ & 0.394 \\
Model 6 & $1.624(0.843-3.127)$ & 0.147 \\
\hline
\end{tabular}

$H R$ indicates hazard ratio, $\mathrm{Cl}$ confidence interval, LVEF left ventricular ejection fraction, NT-proBNP N-terminal pro-B type natriuretic peptide

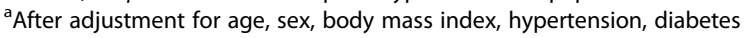
mellitus, dyslipidemia, smoking, family history of coronary artery disease, prior stroke, clinical presentation (myocardial infarction vs. angina), LVEF, NTproBNP, and estimated glomerular filtration rate
Nevertheless, the present results may be translated meaningfully by expanding further studies in the future. To summarize, in previous studies, sNEP levels were associated with long-term prognosis in patients with HFrEF or acute HF, whereas they were not associated with outcomes in patients with HFpEF. In addition, the combination of a NEP inhibitor with angiotensin receptor blocker demonstrated superior clinical outcomes in patients with HFrEF and a greater reduction in the NT-proBNP concentration in patients with acute decompensated HF than did an angiotensin-converting enzyme inhibitor alone, while the combination therapy did not result in a significantly lower rate of the clinical outcome among patients with HFpEF. On the basis of these previous results and our results, serum sNEP levels can be used to predict the long-term prognosis of patients with ischemic heart disease accompanied by chronic HFrEF or acute HF or CAD patients with reduced LVEF, and further findings will support the importance of NEP inhibition in those populations concerning better clinical outcomes.

Previous studies showed that SNEP levels were lower in HFpEF compared with controls without HFpEF, and the lowest sNEP tertile group had the highest prevalence of diastolic dysfunction in general population [6, 35]. The other study found that plasma NEP concentration was lower in non-acute decompensated HF than acute decompensated HF and higher in chronic HF than acute decompensated HF [36]. The same study demonstrated different patterns in distributions of immunoreactive $\mathrm{N}$ type natriuretic peptides or circulating neprilysin activity. The action mechanisms of NEP, such as interaction between NEP and numerous vasoactive peptides or relationship between SNEP activity and concentration, have remained unknown. Our study found that serum sNEP levels were lower in CAD patients with reduced LVEF compared with those with preserved LVEF. Further investigations are needed to elucidate this paradoxical 
Table 5 Association between clinical characteristics and the risk of all-cause death during follow-up analyzed by univariate and multivariate Cox proportional hazard model

\begin{tabular}{|c|c|c|c|c|}
\hline & \multicolumn{2}{|l|}{ Univariate } & \multicolumn{2}{|l|}{ Multivariate } \\
\hline & $\mathrm{HR}(95 \% \mathrm{Cl})$ & $P$ value & $\mathrm{HR}(95 \% \mathrm{Cl})$ & $P$ value \\
\hline$\overline{\text { Age }}$ & $1.110(1.075-1.146)$ & $<0.001$ & $1.077(1.027-1.130)$ & 0.002 \\
\hline Female & $1.748(0.991-3.085)$ & 0.054 & $1.133(0.594-2.160)$ & 0.705 \\
\hline Body mass index & $0.917(0.880-0.956)$ & $<0.001$ & $1.037(0.938-1.147)$ & 0.473 \\
\hline Hypertension & $1.885(0.913-3.891)$ & 0.087 & $1.099(0.465-2.600)$ & 0.830 \\
\hline Diabetes mellitus & $1.414(0.802-2.495)$ & 0.232 & & \\
\hline Dyslipidemia & $1.008(0.547-1.856)$ & 0.980 & & \\
\hline Smoking & $0.487(0.228-1.040)$ & 0.063 & $1.234(0.523-2.915)$ & 0.631 \\
\hline Family history of CAD & $0.527(0.128-2.171)$ & 0.375 & & \\
\hline Chronic kidney disease & $2.472(0.979-6.243)$ & 0.055 & $0.957(0.303-3.018)$ & 0.940 \\
\hline Prior stroke & $1.436(0.644-3.200)$ & 0.377 & & \\
\hline Acute myocardial infarction & $4.320(2.153-8.671)$ & $<0.001$ & $3.191(1.502-6.776)$ & 0.003 \\
\hline Left ventricular ejection fraction & $0.947(0.929-0.965)$ & $<0.001$ & $0.967(0.942-0.994)$ & 0.015 \\
\hline eGFR & $0.960(0.948-0.973)$ & $<0.001$ & $0.983(0.960-1.007)$ & 0.173 \\
\hline NT-proBNP & $1.000(1.000-1.000)$ & $<0.001$ & $1.000(1.000-1.000)$ & 0.420 \\
\hline Multivessel disease & $1.009(0.548-1.857)$ & 0.978 & & \\
\hline Number of total stents & $0.992(0.764-1.290)$ & 0.954 & & \\
\hline Mean diameter of stents & $0.745(0.363-1.528)$ & 0.421 & & \\
\hline Total length of stents & $1.006(0.998-1.013)$ & 0.168 & & \\
\hline Neprilysin > $76.0 \mathrm{pg} / \mathrm{ml}$ & $1.437(0.810-2.552)$ & 0.215 & $1.558(0.848-2.863)$ & 0.153 \\
\hline
\end{tabular}

$H R$ indicates hazard ratio, $C l$ confidence interval, CAD coronary artery disease, eGFR estimated glomerular filtration rate, NT-proBNP N-terminal pro-B-type natriuretic peptide

\begin{tabular}{|c|c|c|c|c|c|c|c|c|c|c|c|}
\hline $\mathbf{A}$ & 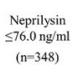 & $\begin{array}{c}\text { Neprilysin } \\
>76.6 \text { ngyml } \\
(n=349)\end{array}$ & & HR (95\% CD) & Interaction $\mathrm{p}$ & B & 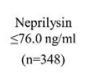 & $\begin{array}{c}\text { Neprilysin } \\
>770.0 \text { ngyml } \\
(n=346)\end{array}$ & & $\mathrm{HR}(95 \% \mathrm{Cl})$ & Interaction $p$ \\
\hline Overall & $20(5.7 \%)$ & $28(8.1 \%)$ & + & $1.437(0.810-2.552)$ & & Overall & $19(5.5 \%)$ & $24(6.9 \%)$ & & $1.307(0.716-2.386)$ & \\
\hline $\begin{array}{l}\mathrm{Age} \leq 70 \\
\mathrm{Age}>70\end{array}$ & $\begin{array}{l}3(1.5 \%) \\
17(11.8 \%)\end{array}$ & $\begin{array}{c}6(2.7 \%) \\
22(18.3 \%)\end{array}$ & 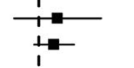 & $\begin{array}{l}1.822(0.456-7.289) \\
1.625(0.863-3.0661)\end{array}$ & 0.880 & $\begin{array}{l}\text { Age } \leq 70 \\
\text { Age }>70\end{array}$ & $\begin{array}{l}8(3.9 \%) \\
11(7.6 \%)\end{array}$ & $\begin{array}{l}9(4.0 \%) \\
15(12.5 \%)\end{array}$ & 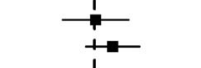 & $\begin{array}{l}1.038(0.400-2.690) \\
1.705(0.783-3.713)\end{array}$ & 0.416 \\
\hline $\begin{array}{l}\text { Male } \\
\text { Female }\end{array}$ & $\begin{array}{l}11(4.8 \%) \\
9(7.7 \%)\end{array}$ & $\begin{array}{l}15(6.4 \%) \\
13(11.6 \%)\end{array}$ & $\begin{array}{l}1 \\
+4 \\
+4\end{array}$ & $\begin{array}{l}1.363(0.626-2.968) \\
1.569(0.670-3.370)\end{array}$ & 0.804 & $\begin{array}{l}\text { Male } \\
\text { Female }\end{array}$ & $\begin{array}{l}10(4.3 \%) \\
9(7.7 \%)\end{array}$ & $\begin{array}{l}8(3.4 \%) \\
16(11.3 \%)\end{array}$ & $\rightarrow$ & $\begin{array}{l}0.806(0.318-2.042) \\
1.949(0.861-4.411)\end{array}$ & 0.160 \\
\hline $\begin{array}{l}\text { Body mass index }<25 \\
\text { Body mass index } \geq 25\end{array}$ & $\begin{array}{l}13(6.6 \%) \\
7(4.6 \%)\end{array}$ & $\begin{array}{l}15(7.9 \%) \\
13(8.3 \%)\end{array}$ & & $\begin{array}{l}1.218(0.580-2.560) \\
1.843(0.735-4.621)\end{array}$ & 0.499 & $\begin{array}{l}\text { Body mass index }<25 \\
\text { Body mass index } \geq 25\end{array}$ & $\begin{array}{l}13(6.6 \%) \\
6(4.0 \%)\end{array}$ & $\begin{array}{l}12(6.3 \%) \\
12(7.6 \%)\end{array}$ & 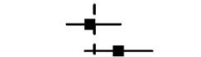 & $\begin{array}{l}0.789(0.446-2.144) \\
2.017(0.757-5.574)\end{array}$ & 0.263 \\
\hline $\begin{array}{l}\text { Hypertension }(-) \\
\text { Hypertension }(+)\end{array}$ & $\begin{array}{l}4(3.6 \% \%) \\
16(6.7 \%)\end{array}$ & $\begin{array}{l}5(5.2 \%) \\
23(9.2 \%)\end{array}$ & $\frac{1}{1}$ & $\begin{array}{l}1.444(0.388-5.378) \\
1.405(0.742-2.660)\end{array}$ & 0.982 & $\begin{array}{l}\text { Hypertension }(-) \\
\text { Hypertension }(+)\end{array}$ & $\begin{array}{l}4(3.6 \%) \\
15(6.3 \%)\end{array}$ & $\begin{array}{l}2(2.1 \%) \\
22(8.8 \%)\end{array}$ & & $\begin{array}{l}0.565(0.104-3.086) \\
1.457(0.756-2.809)\end{array}$ & 0.315 \\
\hline $\begin{array}{l}\text { Diabetes }(-) \\
\text { Diabetes }(+)\end{array}$ & $\begin{array}{l}10(4.8 \%) \\
10(7.2 \%)\end{array}$ & $\begin{array}{l}16(7.2 \%) \\
12(9.7 \%)\end{array}$ & & $\begin{array}{l}1.558(0.707-3.433) \\
1.349(0.583-3.122)\end{array}$ & 0.810 & $\begin{array}{l}\text { Diabetes }(-) \\
\text { Diabetes }(+)\end{array}$ & $\begin{array}{l}8(3.8 \%) \\
11(8.0 \%)\end{array}$ & $\begin{array}{l}10(4.5 \%) \\
14(11.3 \%)\end{array}$ & & $\begin{array}{l}1.206(0.476-3.056) \\
1.477(0.670-3.254)\end{array}$ & 0.759 \\
\hline $\begin{array}{l}\text { Smoking (-) } \\
\text { Smoking (+) }\end{array}$ & $\begin{array}{l}16(6.2 \%) \\
4(4.4 \%)\end{array}$ & $\begin{array}{l}24(10.2 \%) \\
4(3.6 \%)\end{array}$ & & $\begin{array}{l}1.680(0.892-3.162) \\
0.835(0.209-3.340)\end{array}$ & 0.367 & $\begin{array}{l}\text { Smoking (-) } \\
\text { Smoking (+) }\end{array}$ & $\begin{array}{l}17(6.6 \%) \\
2(2.2 \%)\end{array}$ & $\begin{array}{l}22(9.3 \%) \\
2(1.8 \%)\end{array}$ & & $\begin{array}{l}1.463(0.777-2.755) \\
0.828(0.117-5.878)\end{array}$ & 0.598 \\
\hline $\begin{array}{l}\text { Angina } \\
\text { Acute myocaridal infaretion }\end{array}$ & $\begin{array}{l}5(28 \%) \\
15(8.8 \%)\end{array}$ & $\begin{array}{c}5(2.7 \%) \\
23(14.1 \%)\end{array}$ & & $\begin{array}{l}0.980(0.2844-3.383) \\
1.651(0.8022-3.165)\end{array}$ & 0.461 & $\begin{array}{l}\text { Angina } \\
\text { Acute nyocaridal infarction }\end{array}$ & $\begin{array}{l}8(4.5 \%) \\
11(6.5 \%)\end{array}$ & $\begin{array}{l}7(3.8 \%) \\
17(10.4 \%)\end{array}$ & & $\begin{array}{l}0.864(0.313-2.383) \\
1.659(0.777-3.541)\end{array}$ & 0.302 \\
\hline \multirow[t]{2}{*}{$\begin{array}{l}\text { LVEF } \geq 40 \% \\
\text { LVEF }<40 \%\end{array}$} & $\begin{array}{l}13(4.3 \%) \\
7(14.6 \%)\end{array}$ & $\begin{array}{l}15(4.9 \%) \\
13(34.2 \%)\end{array}$ & & $\begin{array}{l}1.138(0.542-2.392) \\
2.630(1.049-6.595)\end{array}$ & 0.150 & $\begin{array}{l}\text { LVEF } \geq 40 \% \\
\text { LVEF }<40 \%\end{array}$ & $\begin{array}{l}15(5.0 \%) \\
4(8.3 \%)\end{array}$ & $\begin{array}{l}15(4.9 \%) \\
9(23.7 \%)\end{array}$ & $\rightarrow$ & $\begin{array}{l}0.991(0.485-2.208) \\
3.213(0.989-10.441)\end{array}$ & 0.083 \\
\hline & & 0.1 & 10 & & & & & & 10 & & \\
\hline
\end{tabular}



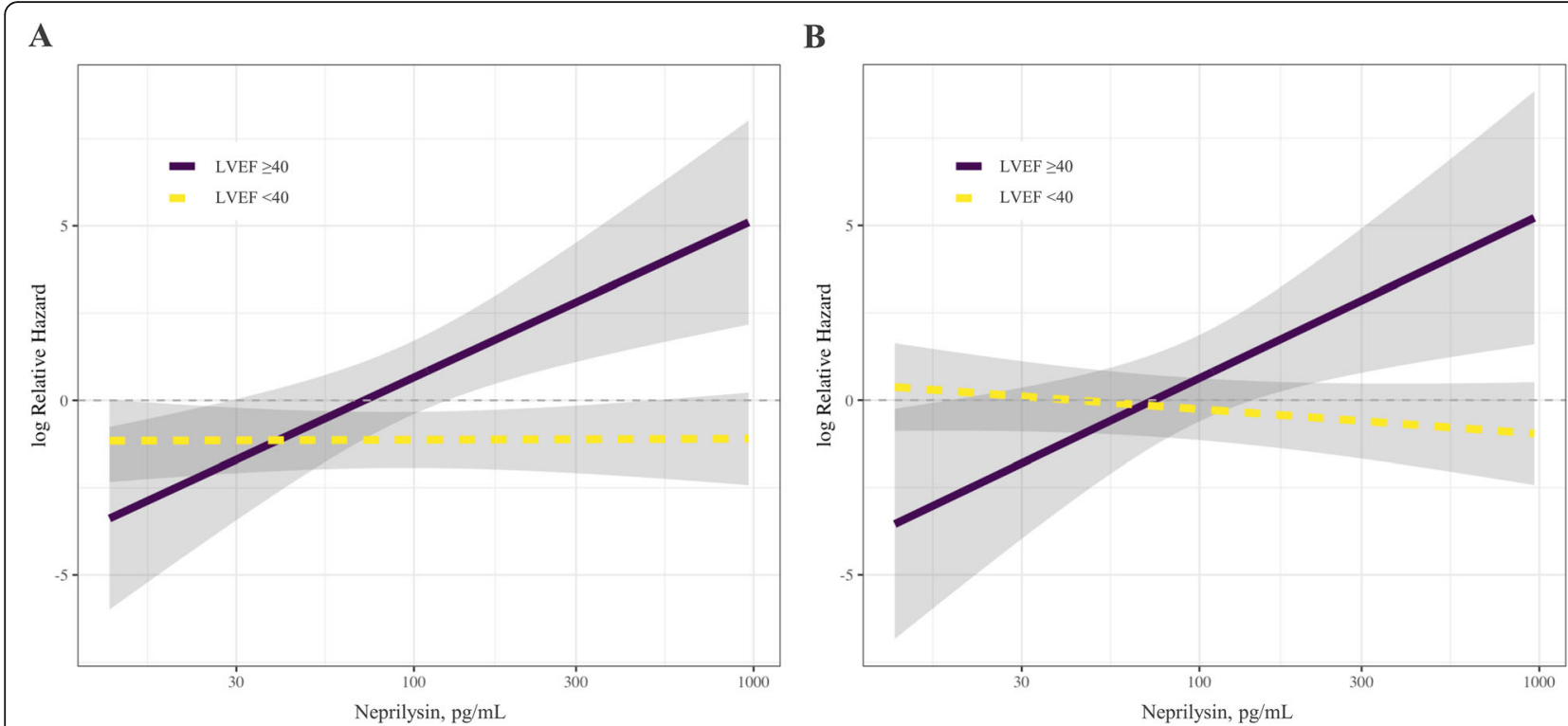

Fig. 5 Longitudinal associations of soluble neprilysin and risk of outcomes according to LVEF after multivariable adjustment. a All-cause death and (b) the major adverse cardiovascular events. Solid purple lines represent the calculated log relative hazard in patients with left ventricular ejection fraction less than 40 , and the dashed yellow line represents the log relative hazard for patients with left ventricular ejection fraction equal to or greater than 40 . Shaded gray areas represent $95 \%$ confidence intervals. LVEF = left ventricular ejection fraction

finding of low concentration and potential prognostic values in patients with reduced LVEF. Furthermore, patients with higher neprilysin level group were younger than lower group. Similar to this study, there was a study that age was negatively associated with level of neprilysin [34]. The mechanism of the negative correlation between age and neprilysin have remained unknown, and further evaluation is needed.

The present study has some limitations. First, we could not assess the biological activity of serum NEP. Therefore, we could not analyze the relationship between serum levels and biological activity and could not adjust these relationships. Second, we collected a blood sample only once per patient at the time of coronary angiography and could not evaluate the changes in sNEP levels. We cannot exclude that changes in SNEP levels are related to longterm clinical outcomes in ischemic heart disease. Third, the blood samples were stored for $1 \sim 2$ years prior to analysis because the ELISAs were performed once after all patients were enrolled. Therefore, some unexpected alterations might have occurred, and these changes could affect the results. Finally, the present study included patients with CAD undergoing PCI, and the results of our study may not be directly applicable to patients with other categories of the disease entity.

\section{Conclusions}

Serum SNEP levels are not associated with the risk of all-cause death and cardiovascular events in patients with CAD undergoing PCI. Among patients with LVEF less than $40 \%$, increased sNEP levels seem to be associated with a higher risk of all-cause death. The prognostic value of SNEP levels may be different depending on whether LVEF is preserved or reduced in ischemic heart disease. Further large-scale studies are needed to verify the results of the present study, and large clinical trials will translate these results into clinical practice to determine whether a NEP inhibitor improves the clinical outcomes in ischemic heart disease with or without decreased left ventricular systolic function.

\section{Abbreviations}

CAD: Coronary artery disease;; Cl: Confidence interval; ELISA: Enzyme-linked immunosorbent assay; HF: Heart failure; HFpEF: Heart failure and preserved ejection fraction; HFrEF: Heart failure and reduced ejection fraction; HR: Hazard ratio; IQR: Interquartile range; LVEF: Left ventricular ejection fraction; MACE: Major adverse cardiovascular events; NEP: Neprilysin; PCI: Undergoing percutaneous coronary intervention; ROC: Receiver operating characteristic; sNEP: Soluble neprilysin

\section{Acknowledgments}

The authors acknowledge Eunsun Kang and Miyoung Youm for their excellent support. The authors are grateful for the cooperation of clinical research coordinators and members of the Institute for Bio-Medical convergence, Incheon St. Mary's Hospital, The Catholic University of Korea.

\section{Authors' contributions}

Conceptualization: I.J.C. and S.L. Methodology: I.J.C., M.J.K., and D.S.J. Statistical analysis: I.J.C., Y.H., D.L., W.J.K., and K.W.L. Supervision: M.J.K., and D.S.J. Writing - original draft: I.J.C. and S.L. Writing - review \& editing: I.J.C., S.L., K.W.K., and D.S.J. All authors have read and approved the manuscript.

\section{Funding}

This project was supported by the Catholic Medical Center Research Foundation made in the program year of 2017 (5-2017-B0001-00249). The funder had no role in the design, conduct, and analysis of this study. 


\section{Availability of data and materials}

The datasets used and/or analyzed during the current study are available from the corresponding author on reasonable request.

\section{Ethics approval and consent to participate}

This study was approved by the Ethics Committee of the Catholic University of Korea, Incheon St. Mary's Hospital. All participants signed informed consent forms.

\section{Consent for publication}

Not applicable.

\section{Competing interests}

All authors declare that they have no conflicts of interest regarding the contents of this article.

\section{Author details}

'Division of Cardiology, Department of Internal Medicine, Incheon St. Mary's Hospital, College of Medicine, The Catholic University of Korea, Seoul, Republic of Korea. ${ }^{2}$ Division of Cardiology, Department of Internal Medicine, Uijeongbu St. Mary's Hospital, College of Medicine, The Catholic University of Korea, 271, Cheonbo-ro, Uijeongbu-si, Gyeonggi-do, 11765 Seoul, Republic of Korea. ${ }^{3}$ Paul H. Chook Department of Information Systems and Statistics, Baruch College, CUNY, New York, NY, USA.

Received: 27 May 2020 Accepted: 20 July 2020

Published online: 06 August 2020

\section{References}

1. Bayes-Genis A, Barallat J, Richards AM. A test in context: Neprilysin: function, inhibition, and biomarker. J Am Coll Cardiol. 2016;68:639-53.

2. Seronde MF, Mebazaa A. Neprilysin: biotarget and biomarker in heart failure. JACC Hear Fail. 2015;3:645-6.

3. Bayés-Genís A. Neprilysin in heart failure: from oblivion to center stage. JACC Hear Fail. 2015;3:637-40.

4. Janssen WM, de Jong PE, van der Hem GK, de Zeeuw D. Effect of human atrial natriuretic peptide on blood pressure after sodium depletion in essential hypertension. Br Med J (Clin Res Ed). 1986;293:351-3.

5. Dillingham MA, Anderson RJ. Inhibition of vasopressin action by atrial natriuretic factor. Science. 1986:231:1572-3.

6. Lyle MA, lyer SR, Redfield MM, Reddy YNV, Felker GM, Cappola TP, et al. Circulating Neprilysin in patients with heart failure and preserved ejection fraction. JACC Hear Fail. 2020;8:70-80.

7. Velazquez EJ, Morrow DA, DeVore AD, Duffy Cl, Ambrosy AP, McCague K, et al. Angiotensin-neprilysin inhibition in acute decompensated heart failure. N Engl J Med. 2019;380:539-48.

8. McMurray JJV, Packer M, Desai AS, Gong J, Lefkowitz MP, Rizkala AR, et al. Angiotensin-neprilysin inhibition versus enalapril in heart failure. N Engl J Med. 2014:371:993-1004

9. Geng Q, Li S, Wang Z, Ren Y. Efficacy and safety of combined neprilysin and RAS inhibition in heart failure: a meta-analysis of randomized controlled trials. Int J Cardiol. 2019;293:159-64. https://doi.org/10.1016/j.ijcard.2019.05.048.

10. Bayés-Genís A, Barallat J, Galán A, De Antonio M, Domingo M, Zamora E, et al. Soluble neprilysin is predictive of cardiovascular death and heart failure hospitalization in heart failure patients. J Am Coll Cardiol. 2015;65:657-65.

11. Bayés-Genís A, Barallat J, Pascual D, Nuñez J, Miñana G, Sánchez-Mas J, et al Prognostic value and kinetics of soluble Neprilysin in acute heart failure. A pilot study. JACC Hear Fail. 2015;3:641-4.

12. Núñez J, Núñez E, Miñana G, Carratalá A, Sanchis J, Lupón J, et al. Serum neprilysin and recurrent hospitalizations after acute heart failure. Int J Cardiol. 2016;220:742-4. https://doi.org/10.1016/j.ijcard.2016.06.271

13. Bernelin H, Mewton N, Si-Mohamed S, Croisille P, Rioufol G, Bonnefoy-

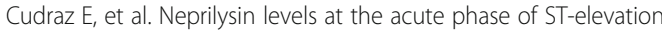
myocardial infarction. Clin Cardiol. 2019;42:32-8.

14. Goliasch G, Pavo N, Zotter-Tufaro C, Kammerlander A, Duca F, Mascherbauer $J$, et al. Soluble neprilysin does not correlate with outcome in heart failure with preserved ejection fraction. Eur J Heart Fail. 2016;18:89-93.

15. Levine GN, Bates ER, Blankenship JC, Bailey SR, Bittl JA, Cercek B, et al. 2011 ACCF/AHA/SCAl guideline for percutaneous coronary intervention: a report of the American College of Cardiology Foundation/American Heart Association task force on practice guidelines and the Society for Cardiovascular Angiography and Interventions. Circulation. 2011;124:e574-651.

16. O'Gara PT, Kushner FG, Ascheim DD, Casey DEJ, Chung MK, de Lemos JA, et al. 2013 ACCF/AHA guideline for the management of ST-elevation myocardial infarction: a report of the American College of Cardiology Foundation/American Heart Association task force on practice guidelines. Circulation. 2013;127:e362-425.

17. Amsterdam EA, Wenger NK, Brindis RG, Casey DEJ, Ganiats TG, Holmes DRJ, et al. 2014 AHA/ACC guideline for the management of patients with nonST-elevation acute coronary syndromes: executive summary: a report of the American College of Cardiology/American Heart Association task force on practice guidelines. Circulation. 2014;130:2354-94.

18. Neumann F-J, Sousa-Uva M, Ahlsson A, Alfonso F, Banning AP, Benedetto U, et al. 2018 ESC/EACTS guidelines on myocardial revascularization. Eur Heart J. 2019:40:87-165.

19. de Bold AJ. Atrial natriuretic factor: a hormone produced by the heart. Science. 1985;230:767-70.

20. Sudoh T, Minamino N, Kangawa K, Matsuo H. C-type natriuretic peptide (CNP): a new member of natriuretic peptide family identified in porcine brain. Biochem Biophys Res Commun. 1990;168:863-70.

21. Sudoh T, Kangawa K, Minamino N, Matsuo H. A new natriuretic peptide in porcine brain. Nature. 1988;332:78-81.

22. Daniels LB, Maisel AS. Natriuretic peptides. J Am Coll Cardiol. 2007;50:2357-68.

23. Bavishi C, Messerli FH, Kadosh B, Ruilope LM, Kario K. Role of neprilysin inhibitor combinations in hypertension: insights from hypertension and heart failure trials. Eur Heart J. 2015;36:1967-73.

24. Dewan P, Docherty KF, McMurray JJV. Sacubitril/valsartan in Asian patients with heart failure with reduced ejection fraction. Korean Circ J. 2019;49:669-84.

25. Potter LR. Natriuretic peptide metabolism, clearance and degradation. FEBS J. 2011;278:1808-17.

26. George SG, Kenny AJ. Studies on the enzymology of purified preparations of brush border from rabbit kidney. Biochem J. 1973;134:43-57.

27. Kerr MA, Kenny AJ. The purification and specificity of a neutral endopeptidase from rabbit kidney brush border. Biochem J. 1974;137:477-88.

28. Braunwald $\mathrm{E}$. The path to an angiotensin receptor antagonist-neprilysin inhibitor in the treatment of heart failure. J Am Coll Cardiol. 2015;65:102941. https://doi.org/10.1016/j.jacc.2015.01.033.

29. Richards AM, Wittert GA, Espiner EA, Yandle TG, Ikram H, Frampton C. Effect of inhibition of endopeptidase 24.11 on responses to angiotensin II in human volunteers. Circ Res. 1992;71:1501-7.

30. Rice Gl, Thomas DA, Grant PJ, Turner AJ, Hooper NM. Evaluation of angiotensin-converting enzyme (ACE), its homologue ACE2 and neprilysin in angiotensin peptide metabolism. Biochem J. 2004;383:45-51.

31. Stephenson SL, Kenny AJ. The hydrolysis of a-human atrial natriuretic peptide by pig kidney microvillar membranes is initiated by endopeptidase24.11. Biochem J. 1987;243:183-7.

32. Kuruppu S, Rajapakse NW, Minond D, Smith Al. Production of soluble Neprilysin by endothelial cells. Biochem Biophys Res Commun. 2014;446: 423-7. https://doi.org/10.1016/j.bbrc.2014.01.158.

33. Yandle T, Richards M, Smith M, Charles C, Livesey J, Espiner E. Assay of endopeptidase-24.11 activity in plasma applied to in vivo studies of endopeptidase inhibitors. Clin Chem. 1992;38:1785-91.

34. Núñez J, Núñez E, Barallat J, Bodí V, Miñana G, Cruz Pastor M, et al. Serum neprilysin and recurrent admissions in patients with heart failure. J Am Heart Assoc. 2017;6:1-9.

35. Reddy YNV, Iyer SR, Scott CG, Rodeheffer RJ, Bailey K, Jenkins G, et al. Soluble Neprilysin in the general population: clinical determinants and its relationship to cardiovascular disease. J Am Heart Assoc. 2019;8:e012943.

36. Vodovar N, Séronde MF, Laribi S, Gayat E, Lassus J, Januzzi JL, et al. Elevated plasma B-type natriuretic peptide concentrations directly inhibit circulating Neprilysin activity in heart failure. JACC Hear Fail. 2015;3:629-36.

\section{Publisher's Note}

Springer Nature remains neutral with regard to jurisdictional claims in published maps and institutional affiliations. 